\title{
PENGARUH EARNING PER SHARE DAN CASH RATIO TERHADAP \\ DIVIDEN PAYOUT RATIO DENGAN ASSET GROWTH SEBAGAI \\ VARIABEL MODERASI PADA SEKTOR INDUSTRI BARANG \\ KONSUMSI DI BEI PERIODE 2009-2012
}

\author{
Muhammad Hidayat \\ Dosen Tetap Prodi Akuntansi Universitas Riau Kepulauan
}

\begin{abstract}
ABSTRACK
This study is performed to examine the effect of Earning Per Share and Cash Ratio toward Dividend Payout Ratio with Asset Growth as a moderating variabel on companies which were consumer goods industry sector listed in Indonesia Stock Exchange over period 2009-2012.

Population of this research were 33 companies. Sample selected by using method of purposive sampling were 15 companies. The data research is secondary data obtained from the Indonesian Stock Exchange (www. idx.co.id). Hypothesis testing studies used linear regression analisys and moderated regression analysis, with application tool of SPSS (Statistical Product and Service Solutions).

From the analysis result indicates that Earning Per Share variable partially significant positive toward Dividend Payout Ratio on the level of significance less than 5\%, while it indicates that Cash Ratio variable not significant positive toward Dividen Payout Ratio. Asset Growth is not able to significantly moderate the effect of Earning Per Share on the Dividend Payout Ratio, Asset Growth is not able to significantly moderate the effect of Cash Ratio on the Dividend Payout Ratio.
\end{abstract}

Keywords: Dividen Payout Ratio, Earning Per Share, Cash Ratio, Asset Growth.

\section{PENDAHULUAN}

Pada umumnya investor menanamkan modalnya di suatu perusahaan untuk mendapatkan keuntungan, baik dalam bentuk dividen maupun capital gain. Namun pihak manajemen perusahaan menginginkan adanya pertumbuhan perusahaan yang berkelanjutan. Dengan demikian diperlukan pertimbangan yang baik untuk 
memutuskan kebijakan dividen yang tepat, sehingga dapat memenuhi harapan para pemegang saham dan sekaligus juga menjaga ketersediaan dana untuk keperluan pertumbuhan perusahaan. Kebijakan dividen dapat dilihat dari porsi laba yang dibagikan dalam bentuk dividen kas atau disebut dengan dividend payout ratio (DPR), besar kecilnya dividend payout ratio bisa mempengaruhi keputusan investasi para investor dan juga berpengaruh pada kondisi keuangan perusahaan. (Marlina dan Danica, 2009).

Kebijakan deviden berhubungan dengan perlakuan manajemen terhadap laba bersih perusahaan, pada umumnya sebagian dari laba bersih setelah pajak dibagikan pada investor dalam bentuk dividen dan sebagian menjadi laba ditahan. Laba ditahan merupakan satu sumber dana untuk membiayai pertumbuhan perusahaan. Tingkat pertumbuhan perusahaan yang tinggi tentunya membutuhkan jumlah dana yang tinggi untuk membiayai investasinya. Kebutuhan dana yang tinggi dimasa depan semakin memungkinkan perusahaan menahan keuntungan dan mengurangi pembayaran deviden. Pertumbuhan perusahaan merupakan hal penting yang mempengaruhi kebijakan deviden

Earning Per Share adalah keuntungan bersih yang diperoleh investor untuk setiap lembar sahamnya. Lubis (2009) menyatakan earning per share dari suatu perusahaan dapat dijadikan indikator untuk menilai apakah suatu perusahaan mampu meningkatkan keuntungannya yang berarti juga meningkatkan kekayaan pemegang sahamnya dengan membagikan dividen. Hal lainnya yang sangat perlu dipertimbangkan sebelum memutuskan besarnya pembayaran deviden kepada pemegang saham adalah Cash ratio. Karena semakin kuat cash ratio perusahaan maka akan semakin besar kemampuan untuk membayar deviden.

Beberapa peneliti telah menguji pengaruh Earning Per Share terhadap Dividen Payout Ratio antara lain adalah Tanti dan Yulias (2012), Deitiana (2009), Priono (2006) menyatakan bahwa Earning Per Share berpengaruh positif dan signifikan terhadap Dividen Payout Ratio.Beberapa peneliti yang telah menguji pengaruh Cash Ratio terhadap kebijakan dividen antara lain adalah Wicaksana (2012), Janifairus at,al (2012), Nadjibah (2008), Andriyani (2008), Priono (2006), Lubis (2009) yang mengatakan bahwa Cash Ratio berpengaruh posistif dan signifikan terhadap Dividen Payout Ratio.

Penelitian ini berbeda dari penelitian-penelitian sebelumnya dimana penelitian sebelumnya melakukan pengujian pengaruh langsung antara earning per share, cash ratio dan asset growth terhadap dividen payout ratio. Dalam penelitian ini lebih difokuskan untuk menguji apakah asset growth memoderasi hubungan earning per share terhadap dividen payout ratio dan apakah asset growth memoderasi hubungan cash ratio terhadap dividen payout ratio. Penelitian ini dilakukan pada perusahaan sektor industri barang konsumsi yang terdaftar di Bursa Efek Indonesia periode tahun 2009 - 2012.

\section{TEORI DAN HIPOTESIS}

\section{Teori keagenan}


Teori keagenan menjelaskan bahwa kepentingan pengelola perusahaan (agent) dan kepentingan pemegang saham (principal) sering kali bertentangan sehingga bisa menimbulkan konflik diantara keduanya (Jansen dan Mekling 1976 dalam kumar 2007) dengan asumsi individu mempunyai kepentingan untuk dirinya sendiri, maka hal ini akan terjadi jika pengelola perusahaan berusaha mengutamakan kepentingan pribadinya dibanding dengan keinginan pemegang saham. Dalam hal ini kepentingan (agent) dapat mengurangi keuntungan perusahaan yang menyebabkan penerimaan pemegang saham (principal) juga menurun.

\section{Teori kebijakan dividen}

Dividen merupakan pembagian keuntungan kepada pemegang saham dari suatu perusahaan secara proporsional sesuai dengan jumlah lembar saham yang dimiliki oleh masing-masing pemegang saham (Stice dan Skousen, Intermediate Accounting 2009). Dividen dibagikan kepada para pemegang saham sebagai keuntungan dari laba perusahaan, jika perusahaan mampu menghasilkan laba yang besar maka semakain memungkinkan dividen yan dibagikan juga akan semakin besar.

\section{Faktor-faktor yang mempengaruhi kebijakan dividen}

Menurut Harjito dan Martono (2005) pertimbangan manajerial dalam menentukan kebijakan dividen adalah :

a. Kebutuhan dana bagi perusahaan

Penghasilan perusahaan akan digunakan terlebih dahulu untuk memenuhi kebutuhan dananya (semua proyek investasi yang menguntungkan) baru setelah itu sisanya untuk dibayarkann sebagai dividen.

b. Likuiditas perusahaan

Semakin tinggi jumlah kas yang tersedia maka dikatakan likuiditas perusahaan semakin tinggi, sehingga semakin besar kemampuan perusahaan untuk membayar dividen.

c. Kemampuan untuk meminjam

Kemampuan yang tinggi untuk mendapatkan pinjaman merupakan suatu fleksibilitas keuangan yang tinggi sehingga kemampuan untuk membayar dividen juga semakin tinggi.

d. Pembatasan dalam perjanjian hutang

Ketentuan perlindungan dalam suatu perjanjian hutang sering menambahkan pembatasan terhadap pembayaran dividen. Hal ini dimaksudkan untuk memastikan kemampuan perusahaan dalam membayar hutangnya.

e. Pengendalian perusahaan

Penambahan modal perusahaan dengan cara menjual saham tentunya akan memungkinkan kelompok pemegang saham tertentu tidak lagi menjadi pengendali perusahaan karena bukan lagi sebagai pemegang saham mayoritas. 
Secara skematis model penelitian dapat digambarkan sebagai berikut

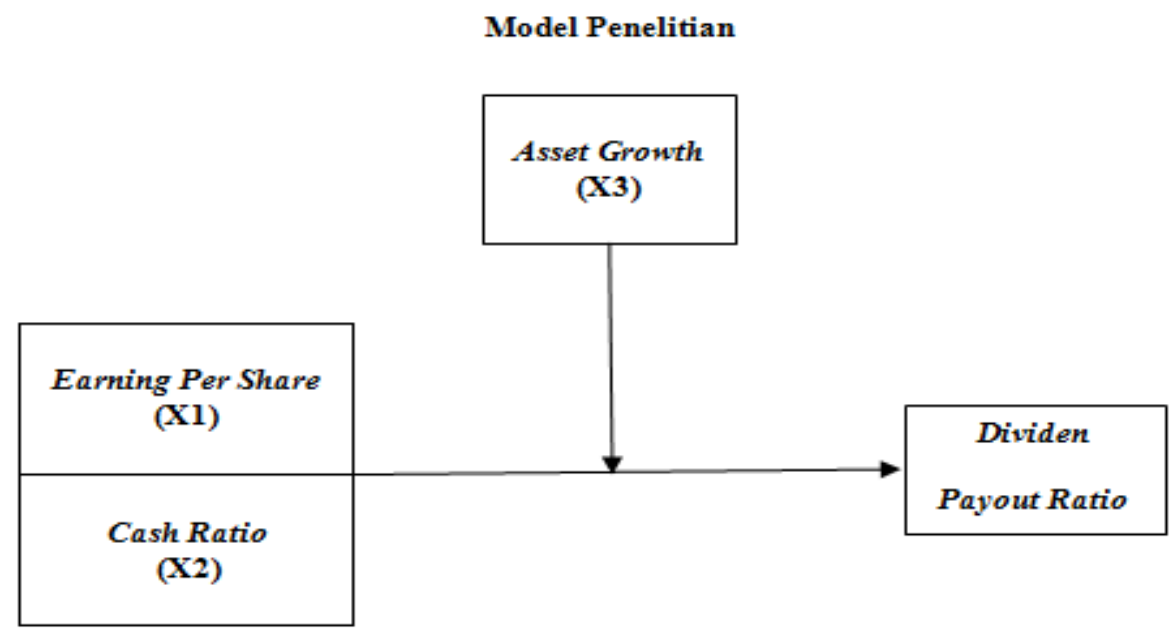

Adapun hipotesis penelitian dapat dirumuskan sebagai berikut :

H1 : Earning per Shares berpengaruh positif terhadap Dividen Payout Ratio.

H2 : Cash Ratio berpengaruh positif terhadap Dividen Payout Ratio

H3: $\quad$ Asset growth memoderasi hubungan antara earning per share dengan dividend payout ratio.

H4: $\quad$ Asset growth memoderasi hubungan antara cash ratio dengan dividend payout ratio.

\section{METODE PENELITIAN}

Populasi penelitian ini adalah seluruh perusahaan sektor industri barang konsumsi yang terdaftar di BEI periode tahun 2009 - 2012 dengan jumlah populasi sebanyak 33 perusahaan. Jumlah sampel yang didapatkan adalah 15 perusahaan yaitu perusahaan yang laporan keuangannya lengkap dan membayar dividen berturut-turut selama periode penelitian.

Adapun operasional Variabel dalam penelitian ini adalah :

1. Dividen Payout Ratio 
Dividen payout ratio didefinisikan sebagai rasio antara dividen per share terhadap earning per share. Menurut Weston dan Brigham (1997). Menurut Harjito, A dan Martono (2005) menyatakan bahwa dividend payout ratio merupakan rasio yang menunjukkan persentase laba perusahaan yang dibayar kepada pemegang saham biasa dalam bentuk dividen kas.

Dirumuskan :

$\mathrm{DPR}=\frac{\text { Dividen per share }}{\text { Earning per share }}$

\section{Earning per Share}

Menurut Irham Fahmi (2011:138) Earning Per Share atau laba per lembar saham merupakan bentuk keuntungan yang didapatkan dari setiap lembar saham biasa yang dimiliki.

Dirumuskan :

EPS $=\frac{\text { Earning After Tax }}{\text { Jlh Rata2 Saham Biasa Beredar }}$

3. Cash Ratio

Cash ratio merupakan kemampuan kas dan setara kas yang dimiliki perusahaan untuk membayar kewajiban lancarnya. Tingkat cash ratio yang semakin tinggi menunjukkan kemampuan kas perusahaan untuk memenuhi kewajiban jangka pendeknya. Cash ratio merupakan salah satu variabel penting yang dipertimbangkan manajemen dalam menetapkan deviden.

Dirumuskan :

$\mathrm{CR}=\frac{\text { Cash }+ \text { Equivalent }}{\text { Current Liability }}$

\section{Asset Growth}

Asset growth ini adalah merupakan perubahan atau tingkat pertumbuhan tahunan dari aset total (Hartono, 2008:372). Tingkat pertumbuhan yang tinggi mengindikasikan kesempatan investasi yang tinggi yang tentu membutuhkan pendanaan, sehingga jika perusahaan harus membayarkan dividen, perusahaan harus mencari dana dari pihak eksternal. Dana dari eksternal tentu akan menimbulkan biaya transaksi, sehingga manajemen harus berpikir kembali untuk membayarkan dividen. Jika ada peluang investasi yang menguntungkan manajemen perusahaan akan lebih tetarik menggunakan dana internal untuk membiayai investasi tersebut. Pertumbuhan aset dapat diukur dengan membagi aset tahun sekarang dikurang aset tahun sebelumnya terhadap total aset tahun sebelumnya (Harahap, 2006:310).

Dirumuskan :

$$
\mathrm{AG}=\frac{T \cdot \operatorname{asset}(t)-T \cdot \operatorname{asset}(t-1)}{\text { Total } \operatorname{asset}(t-1)}
$$

Penelitian ini dianalisis dengan menggunakan analisis statistik yaitu :

a) Menguji pengaruh Earning per share terhadap Dividen payout ratio 
Analisis regresi linier sederhana.

$\mathrm{Y}=\alpha+\mathrm{b} 1 \mathrm{X} 1+\mathrm{ei}$

b) Menguji pengaruh Cash ratio terhadap Dividen payout ratio

Analisis regresi linier sederhana.

$\mathrm{Y}=\alpha+\mathrm{b} 1 \mathrm{X} 2+\mathrm{ei}$

c) Menguji apakah asset growth mampu memoderasi hubungan antara earning per share dengan dividen payout ratio.

Model Persamaan Moderated Regression Analysis (MRA).

$\mathrm{Y}=\alpha+\mathrm{b} 1 \mathrm{X} 1+\mathrm{b} 2 \mathrm{X} 3+\mathrm{b} 3 \mathrm{X} 1 . \mathrm{X} 3+\mathrm{ei}$

$\mathrm{Y}=$ Dividen Payout Ratio

$\alpha \quad=$ Konstanta

b1-b3 = Koefisien regresi

$\mathrm{X} 1=$ Earning per share

$\mathrm{X} 3=$ Asset growth

$\mathrm{X} 1 \mathrm{X} 3$ = Interaksi antara Earning per share dengan asset growth

ei = Error Term, yaitu tingkat kesalahan penduga dalam penelitian

d) Menguji apakah asset growth mampu memoderasi hubungan antara cash ratio dengan dividen payout ratio.

Model Persamaan Moderated Regression Analysis (MRA).

$\mathrm{Y}=\alpha_{1} 1+\mathrm{X} 2+\mathrm{b} 2 \mathrm{X} 3+\mathrm{b} 3 \mathrm{X} 2 . \mathrm{X} 3+\mathrm{ei}$

$\mathrm{Y}=$ Dividen Payout Ratio

$\alpha \quad=$ Konstanta

b1-b3 = Koefisien regresi

$\mathrm{X} 2=$ Cash ratio

$\mathrm{X} 3=$ Asset growth

$\mathrm{X} 2 \mathrm{X} 3$ = Interaksi antara Cash ratio dengan asset growth .

ei $\quad=$ Error Term, yaitu tingkat kesalahan penduga dalam penelitian

\section{HASIL PENELITIAN}

\section{Uji Normalitas}

Salah satu asumsi penting dalam melakukan penelitian dengan regresi adalah bahwa data telah berdistribusi secara normal. Dengan demikian perlu dilakukan Uji Normalitas yang bertujuan untuk menguji apakah dalam model regresi, variabel independen, dependen dan moderasi terdistribusi secara normal atau tidak.

Menurut Ghozali (2006), untuk mengetahui normalitas data dapat dilakukan dengan melihat penyebaran data pada sumbu diagonal dari grafik, yaitu jika data menyebar di sekitar garis diagonal dan mengikuti arah garis diagonal, hal ini menunjukkan bahwa data telah terdistribusi secara normal. Pengujian dengan metode grafik kadang bisa menimbulkan perbedaan persepsi diantara pengamat sehingga dalam penelitian ini penulis memilih untuk menggunakan metode statistik dengan menggunakan uji Kolmogorov Smirnov, meskipun dari banyaknya metode uji normalitas tidak dapat dikatan bahwa salah satu metode lebih baik dibandingkan metode lainnya. Berikut ini adalah tabel hasil uji normalitas dengan menggunakan uji Kolmogorov Smirnov : 
Tabel 4.2

Uji Normalitas

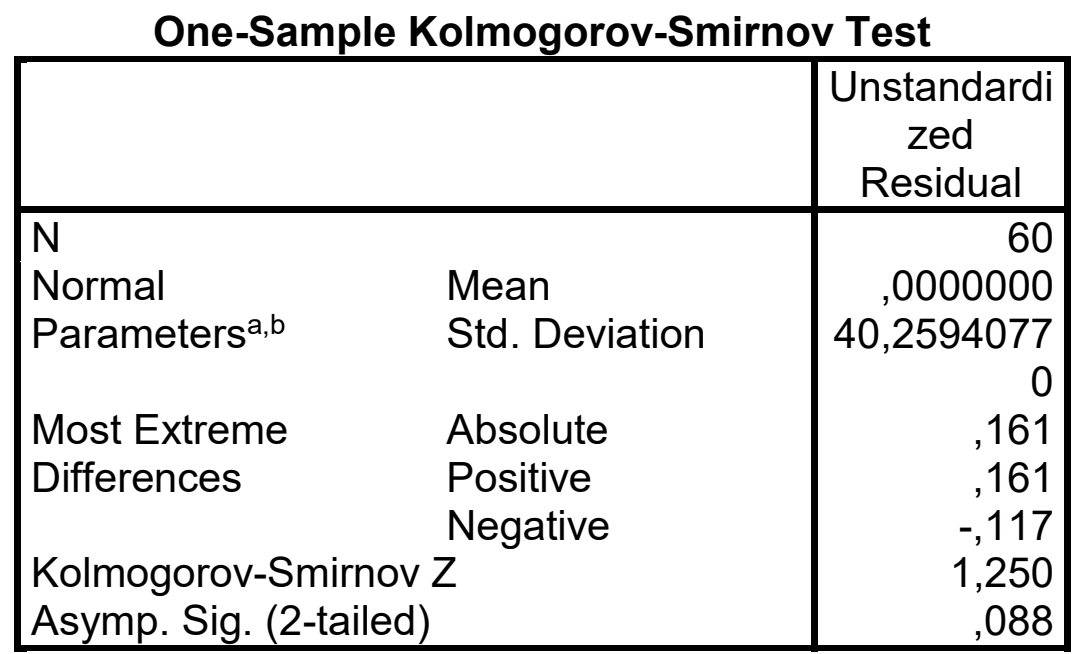

a. Test distribution is Normal.

b. Calculated from data.

Dari hasil uji tersebut diatas dapat dilihat bahwa nilai signifikan $>$ alpha $(0.088>$ 0.05) sehingga dinyatakan bahwa data terdistribusi normal sehingga kita dapat melanjukan dengan uji asumsi klasik lainnya.

\section{Uji Heteroskedastisitas}

Model regresi yang baik adalah tidak terjadi heterokedastisitas. Uji ini dilakukan untuk mengetahui apakah dalam model regresi terjadi ketidak samaan variansi dari residual dari satu pengamatan kepengamatan lainnya. Apabila variansi dari residual satu pengamatan ke pengamatan lainnya tetap maka dikatakan sebagai homoskedastisitas. Untuk melakukan uji heteroskedastisitas dalam hal ini dilakukan dengan metode Glejser sebagai berikut : 
Tabel 4.3

Uji Heteroskedastisitas

Coefficients $^{a}$

\begin{tabular}{|c|c|c|c|c|c|}
\hline \multirow[b]{2}{*}{ Model } & \multicolumn{2}{|c|}{$\begin{array}{l}\text { Unstandardized } \\
\text { Coefficients }\end{array}$} & \multirow{2}{*}{$\begin{array}{c}\begin{array}{c}\text { Standardize } \\
d \\
d \\
\text { Coefficients }\end{array} \\
\text { Beta }\end{array}$} & \multirow[b]{2}{*}{$\mathrm{t}$} & \multirow[b]{2}{*}{ Sig. } \\
\hline & $B$ & Std. Error & & & \\
\hline $\begin{array}{l}1 \text { (Constan } \\
\text { t) }\end{array}$ & 30,311 & 8,988 & & 3,372 & ,001 \\
\hline EPS & , 001 & ,001 & 160 & ,909 & 367 \\
\hline CR &,- 064 & ,052 &,- 221 & $-1,236$ & 222 \\
\hline$A G$ & 180 & ,377 & ,067 & 479 & 634 \\
\hline
\end{tabular}

a. Dependent Variable: ABS_RES1

Dengan melihat bahwa nilai sig dan alpha $=0.05$, maka dari tabel diatas dapat dilihat bahwa untuk semua variabel independen nilai sig $>0.05$, hal ini menunjukkan bahwa penelitian ini terbebas dari gejala heteroskedastisitas.

\section{Uji Autokorelasi}

Adapun uji autokorelasi ini dilakukan untuk mengetahui apakah terjadi korelasi antara satu periode $t$ dengan periode sebelumnya (t-1) sehingga uji autokorelasi ini hanya dilakukan terhadap data time series. Karena analisis regresi adalah untuk melihat pengaruh antara variabel bebas terhadap variabel terikat jadi tidak boleh ada korelasi antara pengamatan dengan data pengamatan sebelumnya. Berikut ini uji statistiks yang digunakan adalah uji autokorelasi dengan Durbin Watson test. Untuk mengetahui ada tidaknya autokorelasi dapat dilihat melalui nilai uji D-W dengan ketentuan sebagai berikut:

$\mathrm{d}<\mathrm{dL} \quad$ : terdapat gejala autokorelasi positif

$\mathrm{d}>(4-\mathrm{dL})$ : terdapat gejala autokorelasi negatif

$\mathrm{dU}<\mathrm{d}<\mathrm{dl}$ : pengujian tidak meyakinkan

$\mathrm{dU}<\mathrm{d}<\mathrm{dl}:$ tidak terdapat gejala autokorelasi

Tabel Uji Autokorelasi - Durbin Watson

Model Summaryb

\begin{tabular}{|l|c|r|r|r|r|}
\hline $\begin{array}{l}\text { Mod } \\
\text { el }\end{array}$ & $\mathrm{R}$ & $\begin{array}{c}\mathrm{R} \\
\text { Square }\end{array}$ & $\begin{array}{c}\text { Adjusted R } \\
\text { Square }\end{array}$ & $\begin{array}{c}\text { Std. Error of } \\
\text { the Estimate }\end{array}$ & $\begin{array}{c}\text { Durbin- } \\
\text { Watson }\end{array}$ \\
\hline 1 &, $325^{\mathrm{a}}$ &, 106 &, 058 & 41,32372 & 1,720 \\
\hline
\end{tabular}

a. Predictors: (Constant), AG, EPS, CR

b. Dependent Variable: DPR (Y)

Dari tabel diatas dapat dilihat bahwa nilai Durbin Watson adalah 1.720 dengan signifikansi 5\% dan jumlah sampel (n) 60 maka dapat diketahui nilai dU $=1,689$ 
sehingga $(4-\mathrm{dU})=4-1,689=2,331$. Karena nilai Durbin Watson terletak diantara dU dan $(4-\mathrm{dU})=1,689<1,720<2,331$ maka dapat dikatakan bahwa penelitian ini bebas dari autokorelasi.

\section{Uji Multikolinearitas}

Uji multikolinearitas ini dilakukan untuk mengetahui apakah ada hubungan linear antara variabel-variabel independen pada model regresi serta untuk mengetahui apakah ada tingkat kolinearitas yang tinggi diantara variabel-variabel independen. Untuk model regresi yang baik seharusnya tidak terdapat korelasi antara variablevariabel independen (tidak terjadi multikonieritas). Adapun suatu model regresi dapat dinyatakan bebas dari multikolinearitas jika memiliki nilai tolerance lebih besar dari $0,1$ (Tolerance $>0,1)$ dan memiliki nilai VIF lebih kecil dari 10 (VIF $<10)$. Berikut ini adalah tabel hasil uji statistik untuk uji multikolinearitas :

\begin{tabular}{|c|c|c|c|}
\hline \multirow{2}{*}{\multicolumn{2}{|c|}{ Model }} & \multicolumn{2}{|c|}{ Collinearity Statistics } \\
\hline & & Tolerance & VIF \\
\hline \multirow[t]{3}{*}{1} & EPS &, 557 & 1,795 \\
\hline & CR &, 536 & 1,867 \\
\hline & AG & 878 & 1,139 \\
\hline
\end{tabular}

Dari tabel 4.5 diatas dapat dilihat bahwa untuk semua variabel bebas memiliki nilai tolerance kurang dari 1 dan nilai VIF semua variabel bebas lebih kecil dari 10, sehingga dapat disimpulkan bahwa tidak terdapat multikolinearitas.

Analisa Regresi

Adapun analisis regresi yang digunakan dalam penelitian ini adalah regresi linier berganda dan Moderated Regression Analysis yaitu dengan uji interaksi. Analisis ini digunakan untuk mengetahui bagaimana pengaruh Earning Per Share dan Cash Ratio terhadap Dividen Payout Ratio secara parsial dan untuk mengetahui apakah Asset Growth mampu memoderasi hubungan tersebut. Hasil analysis regresi dapat dilihat pada tabel berikut ini :

Tabel Regresion - parsial 1

Coefficients $^{\mathrm{a}}$

\begin{tabular}{|c|c|c|c|c|c|c|}
\hline \multirow[b]{2}{*}{ Model } & & \multicolumn{2}{|c|}{ Unstandardized Coefficients } & \multirow{2}{*}{$\begin{array}{c}\begin{array}{c}\text { Standardized } \\
\text { Coefficients }\end{array} \\
\text { Beta }\end{array}$} & \multirow[b]{2}{*}{$t$} & \multirow[b]{2}{*}{ Sig. } \\
\hline & & $\mathrm{B}$ & Std. Error & & & \\
\hline 1 & (Constant) & 54,059 & 6,171 & & 8,760 &, 000 \\
\hline & EPS &, 003 &, 001 &, 310 & 2,487 &, 016 \\
\hline
\end{tabular}

a. Dependent Variable: DPR(Y)

Tabel Regresion - Moderator 1 Coefficients $^{\mathrm{a}}$

\begin{tabular}{|c|c|c|c|c|c|c|}
\hline \multirow{2}{*}{\multicolumn{2}{|c|}{ Model }} & \multicolumn{2}{|c|}{ Unstandardized Coefficients } & \multirow{2}{*}{$\begin{array}{c}\begin{array}{c}\text { Standardized } \\
\text { Coefficients }\end{array} \\
\text { Beta }\end{array}$} & \multirow[b]{2}{*}{$t$} & \multirow[b]{2}{*}{ Sig. } \\
\hline & & $B$ & Std. Error & & & \\
\hline$\overline{1}$ & (Constant) & 53,962 & 11,485 & & 4,698 &, 000 \\
\hline & EPS &, 003 &, 002 & 257 & 1,414 & 163 \\
\hline & $A G$ &,- 031 &, 661 &,- 008 &,- 048 &, 962 \\
\hline & Moderat_1 & $9,330 E-5$ &, 000 & 099 &, 534 &, 596 \\
\hline
\end{tabular}


Berdsarkan tabel 4.8 maka dapat dibuat persamaan regresi sebagai berikut :

a). Analisis regresi linier sederhana

$\mathrm{Y}=54,056+0,003 \mathrm{Xi}+\mathrm{ei}$

Pada persamaan tersebut nilai konstan adalah 54,056, ini merupakan nilai Dividen Payout Ratio (Y) jika tidak ada pengaruh dari variabel Earning Per Share (X1).

b). Model Persamaan Moderated Regression Analisys (MRA).

$\mathrm{Y}=53,962+0,003 \mathrm{Xi}-0,031 \mathrm{X} 3+0,000 \mathrm{X} 1 . \mathrm{X} 3+\mathrm{ei}$

Dari persamaan regresi liniear berganda tersebut diatas dapat dilihat nilai konstanta sebesar 53,962. Hal ini mengindikasikan bahwa nilai dividen payout ratio (Y) mempunyai nilai sebesar 53,962 jika tidak dipengaruhi oleh Earning Per Share, Asset Growth dan variabel moderator-1.

\begin{tabular}{|c|c|c|c|c|c|c|}
\hline \multicolumn{7}{|c|}{$\begin{array}{c}\text { Regresion - parsial } 2 \\
\text { Coefficients }^{\mathrm{a}}\end{array}$} \\
\hline \multirow[b]{2}{*}{ Model } & & \multicolumn{2}{|c|}{ Unstandardized Coefficients } & $\begin{array}{l}\text { Standardized } \\
\text { Coefficients }\end{array}$ & \multirow[b]{2}{*}{$t$} & \multirow[b]{2}{*}{ Sig. } \\
\hline & & $\mathrm{B}$ & Std. Error & Beta & & \\
\hline & (Constant) & 55,144 & 8,630 & & 6,390 &, 000 \\
\hline & $C R$ &, 058 &, 056 & 135 & 1,036 & ,304 \\
\hline
\end{tabular}

\begin{tabular}{|c|c|c|c|c|c|c|}
\hline \multicolumn{7}{|c|}{$\begin{array}{c}\text { Regresion - Moderator } 2 \\
\text { Coefficients }^{\mathrm{a}}\end{array}$} \\
\hline \multirow[b]{2}{*}{ Model } & & \multicolumn{2}{|c|}{ Unstandardized Coefficients } & $\begin{array}{l}\text { Standardized } \\
\text { Coefficients }\end{array}$ & \multirow[b]{2}{*}{ t } & \multirow[b]{2}{*}{ Sig. } \\
\hline & & $B$ & Std. Error & Beta & & \\
\hline 1 & (Constant) & 58,002 & 14,954 & & 3,879 &, 000 \\
\hline & $\mathrm{CR}$ & .032 & .084 & .076 & 384 & 702 \\
\hline & AG & -232 & ,778 &,- 058 &,- 298 & ,767 \\
\hline 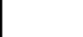 & Moderat_2 &, 003 &, 006 &, 088 &, 430 & 669 \\
\hline
\end{tabular}


Berdasarkan tabel 4.7 maka dapat dibuat persamaan regresi sebagai berikut :

a) Analisis regresi linier sederhana.

$\hat{\mathrm{Y}}=55,144-0,058 \mathrm{X} 2+\mathrm{ei}$

Pada persamaan tersebut nilai konstanta adalah 55,144, ini merupakan nilai dividen payout ratio (Y) jika tidak ada pengaruh dari variabel Cash Ratio (X2).

b) Model Persamaan Moderated Regression Analysis (MRA).

$\hat{\mathrm{Y}}=58,002+0,032 \mathrm{X} 2-0.232 \mathrm{X} 3+0.003 \mathrm{X} 2 . \mathrm{X} 3+\mathrm{ei}$

Dari hasil persamaan regresi linier berganda tersebut diatas dapat dilihat nilai konstanta sebesar 58,002, hal ini mengindikasikan bahwa nilai dividen payout ratio (Y) mempunyai nilai sebesar 58,002 jika tidak dipengaruhi oleh Cash Ratio, Asset Growth dan variabel moderat_2.

\section{Uji t (Uji Signifikansi Parameter Individual )}

Adapun tujuan dilakukannya uji statistik $t$ ini adalah untuk mengetahui seberapa jauh pengaruh suatu variabel independen secara individual dalam menerangkan variasi variabel dependen (Kusumadilaga, 2010). Hasil pengolahan melalui SPSS dapat dijelaskan sebagai berikut :

1) Hipotesis 1

Earning Per Share berpengaruh positif terhadap Dividen Payout Ratio.

Pengujian hipotesis pengaruh variabel Earning Per Share terhadap Dividen Payout Ratio dapat dilihat pada tabel 4.6 dimana tingkat signifikansi sebesar 0,016, angka ini lebih kecil jika dibandingkan dengan level of significance 0,05 atau $(0,016<0,05)$. Dengan demikian dapat 
disimpulkan bahwa Earning Per Share berpengaruh positif dan signifikan terhadap Dividen Payout Ratio.

2) Hipotesis 2

Cash Ratio berpengaruh positif terhadap Dividen Payout Ratio.

Pengujian hipotesis pengaruh variabel Cash Ratio terhadap Dividen Payout Ratio dapat dilihat pada tabel 4.7 dimana tingkat signifikansi sebesar 0,304 lebih besar dari level of significance 0,05 atau $(0,304>0,05)$. Dengan demikian dapat disimpulkan bahwa Cash Ratio berpengaruh positif tidak signifikan terhadap Dividen Payout Ratio.

3) Hipotesis 3

Asset Growth memoderasi hubungan antara Earning Per Share dengan Dividen Payout Ratio.

Pengujian hipotesis pengaruh variabel moderasi Asset Growth terhadap hubungan antara Earning Per Share dengan Dividen Payout Ratio dapat dilihat pada tabel 4.6 dimana tingkat signifikansi 0,596 dimana nilai signifikansi ini lebih besar dari dari level of significance 0,05 atau $(0,596>$ 0,05), yang berarti bahwa Asset Growth tidak mampu secara signifikan memoderasi pengaruh Earning Per Share terhadap Dividen Payout Ratio.

4) Hipotesis 4

Asset Growth memoderasi hubungan antara Cash Ratio dengan Dividen Payout Ratio.

Pengujian hipotesis pengaruh variabel moderasi Asset Growth terhadap hubungan antara Earning Per Share dengan Dividen Payout Ratio dapat dilihat pada tabel 4.7 dimana tingkat signifikansi 0,669 dimana nilai signifikansi ini lebih besar dari dari level of significance 0,05 atau $(0,669>$ 0,05), yang berarti bahwa Asset Growth tidak mampu secara signifikan memoderasi pengaruh Earning Per Share terhadap Dividen Payout Ratio.

\section{Implikasi Penelitian}

Variabel yang terbukti mendukung teori yang ada dalam penelitian ini adalah hubungan antara Earning Per Share dengan Dividen Payout Ratio. Dari hasil pengujian menunjukkan bahwa Earning Per Share berpengaruh posistif dan signifikan terhadap Dividen Payout Ratio.

Hasil penelitian ini menunjukkan bahwa Cash Ratio berpengaruh positif dan tidak signifikan terhadap Dividen Payout Ratio. Hal ini tidak sejalan dengan beberapa penelitian sebelumnya yang menyatakan bahwa Cash Ratio berpengaruh positif signifikan terhadap Dividend Payout Ratio. Hal ini mungkin BISA disebabkan oleh perbedaan periode penelitian dan perbedaan jenis perusahaan yang menjadi objek peneitian. Hal lainnya adalah bahwa perusahaan-perusahaan tersebut adalah perusahaan-perusahaan go publik dengan kemampuan menghasilkan laba yang cukup baik yang ditunjukkan dari konsistensinya dalam melakukan pembayaran dividen, sehingga lebih mudah untuk mendapatkan fasilitas pendanaan dari perbankan. Hal ini sejalan dengan (Harjito dan Martono, 2005) yang menyatakan bahwa jika perusahaan mempunyai kemampuan yang tinggi untuk mendapatkan pinjaman, ini fleksibilitas keuangannya yang tinggi sehingga kemampuan untuk membayar dividen juga tidak terganggu.

Dalam penelitian ini Asset Growth tidak memoderasi pengaruh Earning Per Share terhadap Dividen Payout Ratio, dan Asset Growth juga tidak memoderasi 
pengaruh Cash Ratio dengan Dividen Payout Ratio hal ini mungkin disebabkan oleh kemudahan perusahaan dalam memperoleh dana pinjaman untuk kebutuhan investasinya sehingga Asset Growth yang tinggi tidak mempengaruhi kemampuan dalam melakukan pembayaran dividen.

\section{KESIMPULAN}

Earning Per Share berpengaruh posistif signifikan terhadap Dividen Payout Ratio. Hal ini menunjukkan bahwa Earning Per Share merupakan salah satu faktor utama yang perlu dipertimbangkan oleh investor untuk memprediksi dividen yang akan dibayarkan. Cash Ratio berpengaruh positif tidak signifikan terhadap Dividen Payout Ratio. Ini menunjukkan bahwa Cash Ratio bukan merupakan faktor utama yang menjadi pertimbangan dalam memprediksi Dividen Payout Ratio. Karena dari hasil penelitian ini Cash Ratio tidak cukup signifikan untuk mempegaruhi kemampuan perusahaan dalam menetukan kebijakan pembayaran dividen. Asset Growth tidak mampu secara signifikan memoderasi pengaruh Earning Per Share terhadap Dividen Payout Ratio. Ini menunjukkan bahwa pada saat Earning Per Share tinggi dan dengan Asset Growth yang juga tinggi tidak akan mampu menciptakan Dividen Payout Ratio yang lebih tinggi. Demikian juga sebaliknya pada saat Earning Per Share rendah dan dengan Asset Growth yang juga rendah tidak akan mampu menciptakan Dividen Payout Ratio yang lebih rendah lagi. Asset Growth tidak mampu secara signifikan memoderasi pengaruh Cash Ratio terhadap Dividen Payout Ratio. Ini menunjukkan bahwa pada saat Cash Ratio tinggi dan dengan Asset Growth yang juga tinggi tidak akan mampu menciptakan Dividen Payout Ratio yang lebih tinggi. Demikian juga sebaliknya pada saat Cash Ratio rendah dan dengan Asset Growth yang juga rendah tidak akan mampu menciptakan Dividen Payout Ratio yang lebih rendah lagi.

Untuk peneliti selanjutnya disarankan untuk menambah variable bebas dengan variabel yang diduga lebih kuat pengaruhnya terhadap Dividen Payout Ratio seperti kepemilikan manajerial, pembayaran dividen sebelumnya, usia perusahaan, return on aset maupun pengaruh faktor-faktor ekonomi makro. Untuk variabel moderator bisa diganti dengan variabel lain yang diduga bisa memoderasi hubungan variabel bebas dengan Dividen Payout Ratio.

\section{DAFTAR PUSTAKA}

Al-Haddad, Waseem, Salleh Al-Sorqan, Sukairi - Musa, dan Mahmood - Nur. 2011. "The Effect of Dividend Policy Stability on the Performance of Banking Sector Listed on Amman Stock Exchange”. International Journal of Humanities and Social Science. Vol. 1 No. 5; May 2011. 
Anil,K and Kapoor,S. 2008. "Determinant of Dividen d Payout Ratio-A Study of IndianInformation Technology Sector". International Research Journal of Finance and Economics.p.63-71.

Appanan, Santhi dan Lee Wei Sim. 2011. "A Study on Leading Determinants of Dividend Policy in Malaysia Listed Companies for Food Industry Under Consumer Product Sector”. 2nd International Conference on Business and Economic Research (2nd ICBER 2011) Proceeding.

Baker, H. Kent, 2009, Dividends and Dividend Policy, JohnWiley \& Sons, Inc.: Amerika Serikat

Fira Puspita. 2009. Analisis Faktor-faktor yang mempengaruhi Kebijakan Dividend Payout Ratio. Tesis Dipublikasikan. Jurusan Manjemen. Universitas Diponegoro. Semarang.

Ghozali, Imam, “ Analisis Multivariate dengan Program SPSS”. Edisi ke 4. Badan Penerbit Universitas Diponegoro : Semarang, 2006.

Hadiwidjaja, Rini Dwiyani dan Lely Fera Triani. 2009. Pengaruh Profitabilitas Terhadap Dividend Payout Ratio pada Perusahaan Manufaktur di Indonesia. Jurnal Organisasi dan Manajemen. Vol. 5, No. 2, Hal: 49-54.

Janifarius at,al, dalam penelitiannya "Pengaruh Return on Asset, Debt to Equity Ratio, Assets Growth, dan Cash Ratio terhadap Dividen Payout Ratio" Studi pada Perusahaan Manufaktur Barang Konsumsi yang Listing di Bursa Efek Indonesia Periode 2008-2010.

Kadir, A. (2010). Analisis Faktor-Faktor yang Mempengaruhi Kebijakan Dividen pada Perusahaan Credit Agencies Go Public di Bursa Efek Indonesia. Jurnal Manajemen dan Akuntansi Vol. 11 No. 1, 10-20.

Kusumajaya, D.K. Oka.2011. "Pengaruh Struktur Modal dan Pertumbuhn Perusahaan terhadap Profitabilitas dan Nili Perusahaan pada Perusahaan Manufaktur di Bursa Efek Indonesia." Tesis. Program Pasca Sarjana Universitas Udayana. Denpasar.

Lubis, Yeti Meliany. 2009. Analisis Faktor-Faktor yang Mempengaruhi Dividen Kas pada Perusahaan Manufaktur Jenis Consumer Goods yang Go Public di Bursa Efek Jakarta. Tesis S2. Universitas Sumatera Utara. Medan

Mariah, Meythi dan Riki Martusa. 2012. Pengaruh Profitabilitas dan Kesempatan Investasi terhadap Kebijakan Dividen Tunai dengan Likuiditas sebagai variabel Moderating pada Emiten Pembentuk Indeks LQ 45 (Perioda 20082010), Seminar Nasional Akuntansi dan Bisnis (SNAB).

Nadjibah (2008) "Analisis Pengaruh Asset Growth Size, Cash Ratio dan Return on Asset terhadap Dividen Payout Ratio" pada perusahaan Asuransi yang terdaftar di BEI Periode tahun 2000-2006. Tesis. Program Pasca Sarjana Universitas Diponegoro Semarang

Okpara, Godwin Chigozie. 2010. "A Diagnosis of the Determinant of Dividend Payout Policy in Nigeria: A Factor Analyctical Approach". American Journal of Scientific Research, ISSN 1450-223X Issue 8(2010), pp.57-67.

Rini Dwiyani Hadiwidjaja. 2007. Analisis Factor-faktor yang mempengaruhi Dividend Payout Ratio pada perusahaan manufaktur di Indonesia . Tesis dipublikasikan. Jurusan Manajemen. Universitas Sumatera Utara. Medan.

Riyanto, B. (2010). Dasar Dasar Pembelanjaan Perusahaan. Yogyakarta: BPFE.

Rumengan, Jemmy “Metodologi Penelitian” Ciptapustaka Media Printis, Bandung, 2013. 
Sartono, Agus. 2010. manajemen Keuangan "Teori dan Aplikasi". Edisi Keempat. Yogyakarta: BPFE.

Sumani. 2011. Analisis Pengaruh Return On Equity, Current Ratio, Debt To Total Assets dan Earning Per Share Terhadap Cash Dividend Pada Perusahaan Non Jasa Keuangan yang Go Public di Bursa Efek Indonesia. Jurnal Aplikasi Manajemen.Jember. Vol. 10, No. 1, ISSN :1693-5241, Hal 60-70.

Sumiadji. 2011. "Analisis Variabel Keuangan yang Mempengaruhi Kebijakan Dividen”. Jurnal Dinamika Akuntansi, Vol. 3. No. 2.

Tanti, Ida Yulias. 2012. Pengaruh Likuiditas, DER, Profitabilitas, dan EPS Terhadap Dividend Payout Ratio pada Emiten Pembentuk Indeks LQ45 Periode 20082010. Jurnal Dinamika Manajemen. Vol. 2, No. 2, Hal: 113-128

Wicaksana, I Gede Ananditha. 2012. Pengaruh Cash Ratio, Debt To Equity Ratio, dan Return On Asset Terhadap Kebijakan Dividen pada Perusahaan Manufaktur di Bursa Efek Indonesia. Tesis. Program Pasca Sarjana Universitas Udayana. Denpasar. 